\title{
The Community Partnership Program BUMDES Catu Graha Mandiri in Gumbrih Tourism Village, Pekutatan, Jembrana, Bali
}

\author{
I Wayan Ruspendi Junaedi ${ }^{1}$ \\ ${ }^{1}$ Management Study Program \\ Dhyana Putra University, Bali, Indonesia \\ ruspendijunaedi@undhirabali.ac.id \\ Gerson Feoh², I Gusti Bagus Rai Utama ${ }^{3 *}$ \\ ${ }^{2}$ Informatics Engineering Study Program, \\ Dhyana Putra University, Bali, Indonesia \\ ${ }^{3}$ Hotel Management Study Program \\ Dhyana Putra University, Bali, Indonesia \\ gerson.feoh@undhirabali.ac.id, raiutama@undhirabali.ac.id
}

(Received March 17, 2021, accepted March 31, 2021)

\begin{abstract}
The partnership program between Dhyana Pura University and Catu Graha Mandiri BUMDES was applied by socialization activity, management training, mentoring, and evaluation. The program used a business management indicator that aims to improve the knowledge and skills of the Catu Graha Mandiri BUMDES community business group members. The partnership programs were measured by Pre-Test and Post-Test Method so that the effectiveness and output of the program can be measured accurately. The program offered the solution in terms of providing assistance and training on the use of appropriate technology in increasing the quantity and quality of production of BUMDES Catu Graha Mandiri Gumbrih Village, as well as making financial reports, providing assistance and training on management, education on ethics and consumer behavior, and training product marketing using social media. The results of this partnership program have been able to improve the services of BUMDES Catu Graha Mandiri Gumbrih to consumers and be able to make financial reports accurately. The sales turnover of partners BUMDES has also increased and developed so that job opportunities are open to the community as well as the addition of new entrepreneurs in Gumbrih Village. The increase in human resources in the application of professional management has also increased, an increase in business production has also occurred, marketing has also increased and financial reports can also be done regularly, and promotions on social media have increased so that the sales turnover of BUMDES partners Catu Graha Mandiri Desa Gumbrih more increasing.
\end{abstract}

Keywords: digital marketing; finance management; technology; tourism village 


\section{Introduction}

\section{Overview of Gumbrih Tourism Village}

The Gumbrih Tourism Village is located between the hills and the coast, with an altitude of 500-700 meters above sea level and a temperature of around 20-28 degrees Celsius. Gumbrih Village is in between; in the north, there are Gumbrih hills, west of Pangyangan village or Jembrana regency administration plantation, east of Pengeragoan village, and south coast or the Indonesian ocean. Geographically, Gumbrih Village has a strategic location because it is located on Jalan Raya Denpasar Gilimanuk, and west of Tabanan Regency. Gumbrih has an area of approximately $7.34 \mathrm{~km}^{2}(733,533 \mathrm{Ha})$ which is a plantation and rice field area with a population of 2,922 people. About $617,533 \mathrm{Ha}$ of Gumbrih Village area are managed as plantation land and $37.00 \mathrm{Ha}$ are managed as paddy fields, $40.00 \mathrm{Ha}$ as residential areas. The Gumbrih community is 2,922 people, most of whose sources of livelihood come from plantations, agriculture, animal husbandry, fisheries, and a small part is engaged in trade and other industries. Figure 1 is a picture of the Gumbrih tourism village office from in front (Adinegara, Sirna, \& Sukmana, 2019).

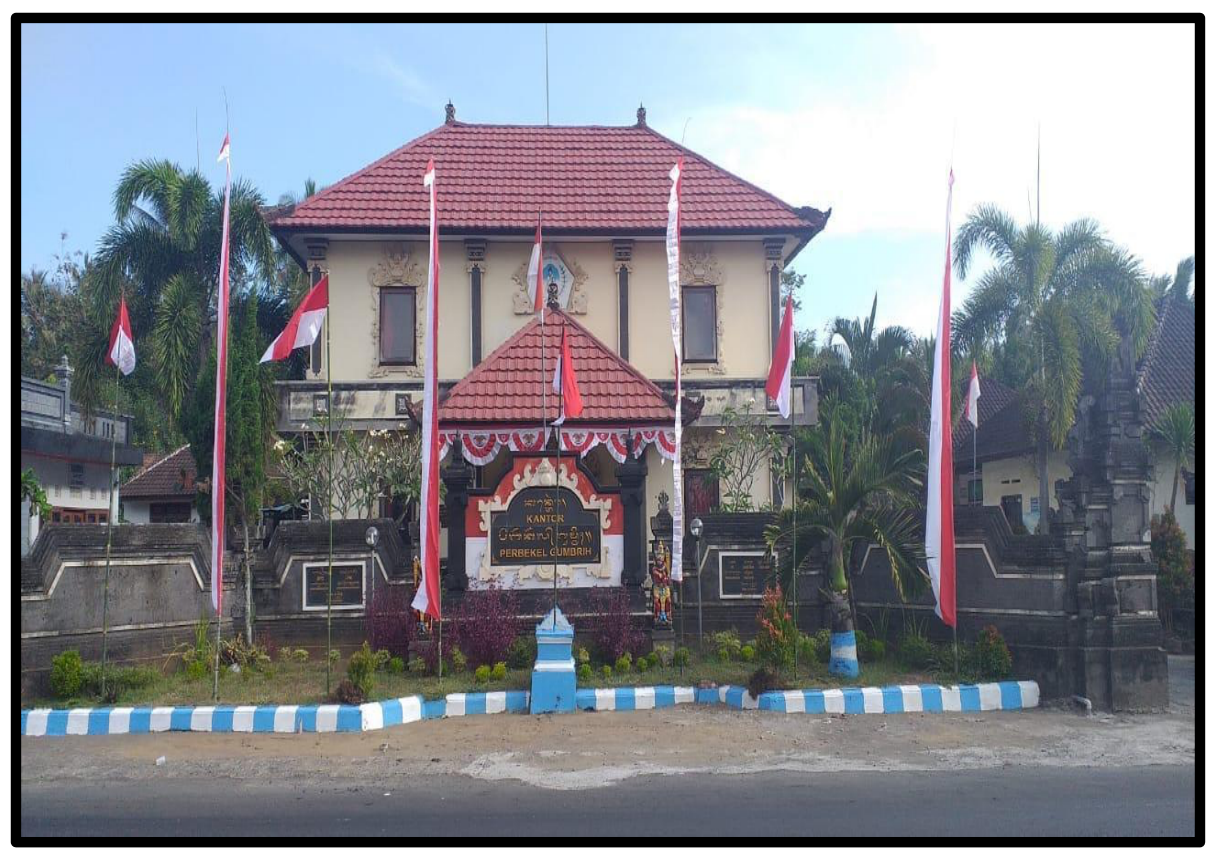

Fig. 1. Gumbrih Tourism Village office

The village has been designated as a Tourism Village based on a Regent Regulation through the Tourism and Culture Office Number 20/PR./DISPARBUD/2017 which relies on plantation and agricultural products, natural beauty, and cultural uniqueness. One of the most well-known 
regional superiorities, namely cacao, coconut, rice, and biological plants (Sukadame Organic Farmers). There are several businesses in Gumbrih Village such as savings and loans, water tourism, trading businesses, Sukadame organic farmers, reptile cages, and ATVs. Entrepreneurship or entrepreneurship into the study warm for its crucial role in economic development (Pratt et al., 2018).

According to Schumpeter (1934) who says that if a country has a lot of entrepreneurs, the country's high economic growth, which will give birth to economic development, is high. If a country wants to develop, the number of entrepreneurs must be large. Entrepreneurship is the driving force behind economic growth. Kirzner said that entrepreneurship is an important part of development. With the Village Owned Enterprise, hereinafter referred to as "BUMDES" Catu Graha Mandiri Desa Gumbrih, will move the materials/raw materials to "change shape" which is more valuable so that consumers finally want to buy it. In this process, there will be an exchange of goods and services, both in the form of natural resources, money, social resources, opportunities, and human resources. In economics, if this happens, it means there is economic growth, and if there is economic growth there is development. But unfortunately for the past few years, the BUMDES Catu Graha Mandiri Desa Gumbrih has not been productive.

One of the causes of failure in achieving economic growth and economic development of a country is the absence of entrepreneurship at the individual, organizational, and community levels. Entrepreneurship plays a very important role in economic development (Kirzner, 1973), is a vital component of productivity and growth (Baumol \& Bowen, 1993), plays a role in increasing investment, new business creation (Gartner, 1985), giving rise to job training (Brown \& Heal, 1979) and home-based business (Spencer Hull, 1986), increasing employment growth (Birch, McPhee, Shoba, Steinberg, \& Krehbiel, 1987), the creation of a national identity and leadership (Bolton, 1971) and together with management capacity is critical to business success (farm performance) (Priyanto \& Sandjojo, 2005). Schumpeter (1934) even states that entrepreneurship is the driving force behind economic growth, formulating new economic combinations by (1) developing new products; (2) developing new sources of materials; (3) accumulating capital resources; (4) introducing new products and new production functions; and (5) reorganizing or developing a new industry.

Entrepreneurship can also have a direct effect on business performance. Baum et al. (2001) stated that the nature of a person (which can be measured by toughness in facing problems, 
proactive attitude, and penchant for work), general competence (which can be measured by organizational skills and ability to see opportunities), specific competencies such as industry expertise and technical expertise, and motivation (which can be measured from vision, growth goals, and self-efficacy), have a positive effect on business growth (Baum, Locke, \& Smith, 2001). Almost in line with Baum et al. (2001), Suci (2009) concluded that entrepreneurial elements such as internal locus of control, need for achievement, extroversion, education experience and self-reliance affect business growth.

\section{Problem Analysis of Partnership}

The paper is about a partnership program for Catu Graha Mandiri BUMDES group in Gumbrih Village, Pekutatan, Jembrana, Bali. The activities were by giving assistance and training on the use of appropriate technology, making financial reports, education on ethics and consumer behavior, and using social media for marketing strategies. These activities are reported as follow:

\section{Management Business Problems}

BUMDES Catu Graha Mandiri is different from other BUMDES in Bali. The BUMDES that have been formed need to be trained in the field of science and technology to map, develop, and regulate the various natural and cultural potentials possessed by the two Subaks in Gumbrih Village with their respective characteristics. Each member of the business group can apply promotional techniques using media social such as Facebook, Twitter, WA, Line, and the like. BUMDES Catu Graha Mandiri Gumbrih Village does not yet have a complete profile of various businesses related to tourism and other aspects as tourist attractions, such as Subak Abian and Subak Sawah.

Subak Abian and Subak Sawah which have tracking tourism objects (ATV), Subak which have tourist objects. Subak Pangkung Srangsang, which has rice terracing tourism objects, Subak Abian which has Ecotourism objects (coconut, chocolate, banana, coffee, various fruits, various vegetables, various flowers, various ceremonial plants, various medicinal plants, and rare plants). So it is necessary to do business marketing promotion training for BUMDES Catu Graha Mandiri Desa Gumbrih for members or Community Groups (POKMAS) in Gumbrih Village to increase the income (revenue) of BUMDES Catu Graha Mandiri Desa Gumbrih. 


\section{Ethics and Consumer Culture Issues}

In addition to trading businesses, water tourism, and reptiles which are tourism objects, it is also developed in six Banjar such as various flowers, various fruit plants, various medicinal plants, various living kitchen plants, various ceremonial plants, and rare plants, and especially chocolate products, in Subak Abian Gumbrih, by the Village Pokmas, it is necessary to guide with a touch of training on ethics and culture or consumer behavior, so that good management can be integrated into the management of tourism villages Ecotourism so that they can provide their characteristics compared to other tourist villages, namely providing customer satisfaction. Likewise, the products that have been and will be produced from the Management of Plants and Cocoa products, it is necessary to seek the legality of their use so that they can be widely used by residents of Gumbrih Village and also tourists who are interested in visiting Gumbrih Village (Utama, Agrotourism as an Alternative Form of Tourism in Bali Indonesia, 2014).

The potential of Biological plants and Chocolate products also needs to be developed in other subak areas because the people in Gumbrih Village have started to become interested in using these products at least for their consumption. this needs to be increased in number to be able to produce more products in the future. Figure 2 is a Photo of Sukadame Organic Farm.

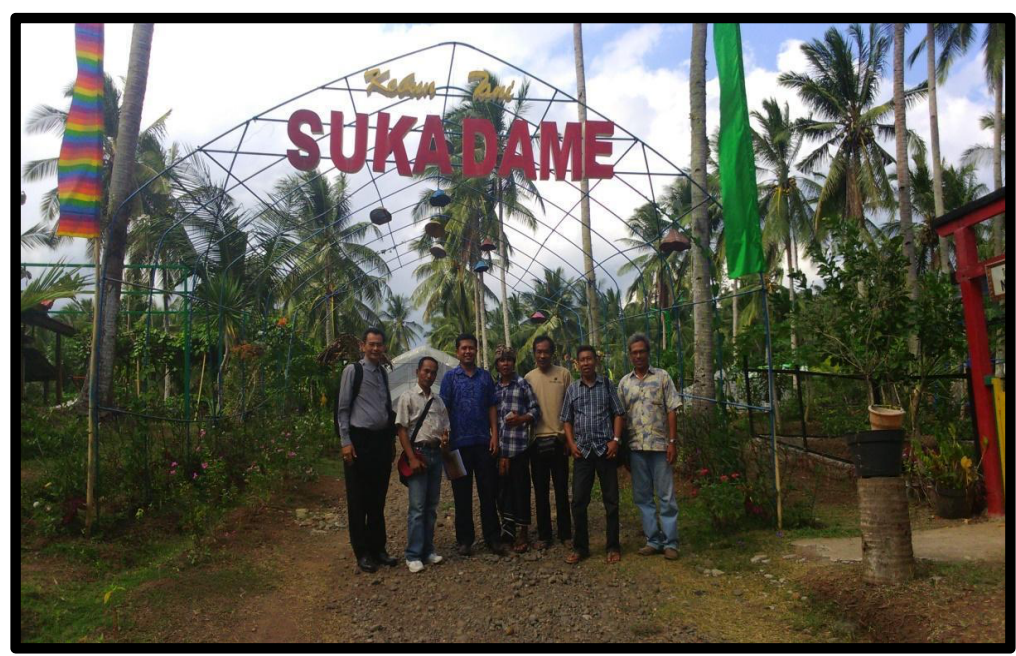

Fig. 2. Sukadame organic farm attraction

\section{Financial Management and Marketing Problems Through Social Media}

BUMDES as a community group business management group (Pokmas) such as savings and loans, trading businesses and water tourism activist groups as well as producing Biological plant products and Chocolate Products need to be given guidance with a touch of technology (information systems) to be able to market business packages and products produced to the 
wider community. Figure 3 is a water tourism attraction as one of the tourist attractions Gumbrih Tourism Village.

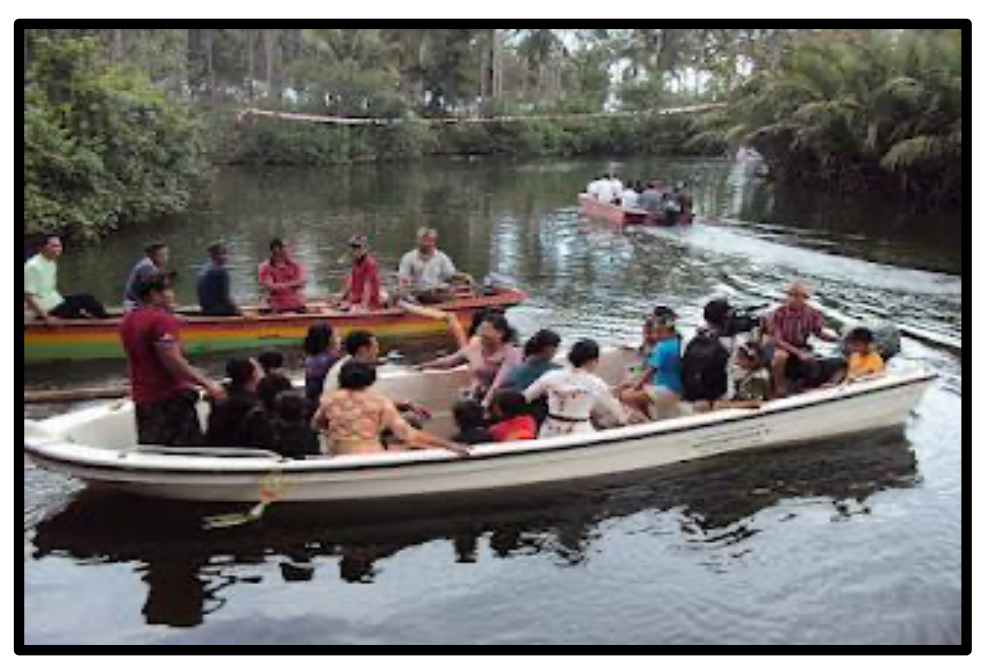

Fig. 3. Water Tourism Attraction

Currently, BUMDES Catu Graha Mandiri does not yet know the terms of marketing both online and offline. Internet training for members of the BUMDES Catu Graha Mandiri Desa Gumbrih needs to be carried out with effective and efficient promotional media. Likewise, BUMDES needs to get assistance in matters related to the preparation of financial reports which are very much needed, especially if more and more tourists are interested in visiting Gumbrih Village. Below is one of the tourist photos in Gumbrih, namely water tourism photos (Utama, Positioning Eco-Tourism for Improving Destination Image of Bali Indonesia, 2016).

\section{Solutions and Targets of Partnership Program}

\section{Solutions}

Catu Graha Mandiri BUMDES has not developed optimally because there are several problems faced so far. Based on the results of observations and complaints as well as the wishes of the BUMDES Catu Graha Mandiri Village Gumbrih group, there are several solutions to solving the problem, namely:

1. Providing assistance, counseling, and training to BUMDES Catu Graha Mandiri to be able to use appropriate technology in accessing the internet and printing for BUMDES financial reports. Therefore, it was helped to purchase a modem for a set and a set of printers in the partner group. The use of appropriate technology can increase BUMDES business so that the sales turnover of BUMDES Catu Graha Mandiri increases every year.

2. Providing assistance, counseling, and training in entrepreneurship management (management professional). Partners are given training on consumer behavior according 
to culture and community ethics (every business group such as trading businesses (shops), reptiles, Organic Farmers Sukadame, and tour packages (such as water tours, and ATV)) By having professional human resources, consumers are satisfied, to increase the knowledge of BUMDES human resources to satisfy consumers.

3. Provide assistance, counseling, and training in the right marketing of products that are members of POKMAS BUMDES using the internet and print media, and social media (FB, IG, and Line). Marketing is the main key in promoting and selling BUMDES products. With the right promotion, it can increase sales turnover and develop this business for the welfare of members of this BUMDES business group and the surrounding community.

\section{Partnership Program Target Partnership}

Program for the Fried Chicken home industry community, Jeng Sri against the Ni Wayan Sri Wahyuningsih group in Gumbrih Ecotourism Tourism Village, Badung Regency; has a target output as shown in the table 2.1 below.

Table 1. University partnership program for BUMDES Catu Graha Mandiri Gumbrih

\begin{tabular}{|c|c|c|c|}
\hline No & Description of programs & Partner Group Target & Technology and Information Tools \\
\hline 1 & $\begin{array}{l}\text { Training and provision } \\
\text { of appropriate technical } \\
\text { assistance in the form of } \\
\text { Smartfren Modems and } \\
\text { Printers and Scan Copy }\end{array}$ & $\begin{array}{l}\text { Partner groups receive } \\
\text { training and assistance in } \\
\text { the use of technology and } \\
\text { assistance } 1 \text { set of W5 wifi } \\
\text { smartfren modem and } 1 \\
\text { printer and Scan Copy } \\
\text { L3110. }\end{array}$ & $\begin{array}{l}\text { The W5 wifi smartfren modem } \\
\text { functions to access the internet and } \\
\text { improve the quality of the internet } \\
\text { users for the promotion of Village- } \\
\text { Owned Enterprises. Printer and Scan } \\
\text { Copy L3110. To streamline technical } \\
\text { matters and help print financial reports }\end{array}$ \\
\hline 2 & $\begin{array}{l}\text { Assistance and training } \\
\text { in entrepreneurship } \\
\text { management and } \\
\text { Business Start-up. }\end{array}$ & $\begin{array}{l}\text { Partner groups receive } \\
\text { Business Start-up training } \\
\text { and assistance in managing } \\
\text { the BUMDES Catu Graha } \\
\text { Mandiri business }\end{array}$ & $\begin{array}{l}\text { Providing an understanding of product } \\
\text { uniqueness, marketing, marketing } \\
\text { mix, BEP, and providing maximum } \\
\text { service to consumers according to } \\
\text { ethics and culture as well as increasing } \\
\text { consumer satisfaction }\end{array}$ \\
\hline 3 & $\begin{array}{l}\text { Assistance and training } \\
\text { in product marketing and } \\
\text { services through print } \\
\text { and social media. }\end{array}$ & $\begin{array}{l}\text { Partner groups receive } \\
\text { product marketing training } \\
\text { through the internet and } \\
\text { print media, Village- } \\
\text { Owned Enterprises, Catu } \\
\text { Graha Mandiri }\end{array}$ & $\begin{array}{l}\text { Marketing via the internet, print media } \\
\text { marketing, and media social, can } \\
\text { increase the number of consumers, } \\
\text { and the turnover of Village-Owned } \\
\text { Enterprises, Catu Graha Mandiri } \\
\text { increases. }\end{array}$ \\
\hline
\end{tabular}




\section{Methods}

Location of the partnership program was carried out at BUMDES Catu Graha Mandiri, Gumbrih Village, Pekutatan District, Jembrana Regency, Bali towards Tabanan towards Gilimanuk. The partnership program between Dhyana Pura University and Catu Graha Mandiri BUMDES was applied by socialization activity, management training, mentoring, and evaluation of the BUMDES Catu Graha Mandiri Gumbrih Village.

We used indicators and business management which aim to improve the knowledge and skills aspects of the Catu Graha Mandiri BUMDES community business group in Gumbrih Village. We measured our partnership program by Pre-Test and Post Test Method so that the effectiveness and output of our program can be measured accurately.

\section{Socialization Phase for Ecotourism Tourism Village}

This socialization phase was carried out by inviting all members of the group to the BUMDES Catu Graha Mandiri, Gumbrih Village, which is managed by the Head of BUMDES Catu Graha Mandiri, Gumbrih Village, Mr. I Made Arka Dana. This socialization will present the Village Head, traditional leaders, religious leaders, and some community members. Dhyana Pura University was attended by the Chancellor, Chair of the Institute for Research and Community Service along with staff, experts, and several lecturers.

The Head of Gumbrih Village will open this socialization event to motivate the community so that this good program from the internal grant of Dhyana Pura University can be carried out as well as possible. Then the Chancellor who was accompanied by the Chairperson of the institute for research and community service gave direction to the implementation team of BUMDES Catu Graha Mandiri Desa Gumbrih to provide assistance, training, and guidance to community business groups.

The head of the implementation team-BUMDES Catu Graha Mandiri, Gumbrih Village, socialized to all members of the existing business group about the activities and benefits of this good program from Univ. Dhyana Pura. This outreach is related to business management, increasing knowledge of consumer behavior, skills in making financial reports, and marketing through social media and the Internet. With this socialization event, all members of the business group who are members of the BUMDES must prepare themselves to take part in the training 
program the next day according to mutual agreement. After Socialization Phase BUMDES Catu Graha Mandiri, Gumbrih Village the knowledge of BUMDES team members has improved better than before partnership activity.

\section{University Partnership Training Phase for BUMDES Catu Graha Mandiri}

The training phase is a follow-up to the socialization program. This training program can be described as follows:

\section{Management business training}

Management Business training is held by disseminating the importance of managing a business for problems related to science and technology Providing assistance, counseling, and training to Catu Graha Mandiri BUMDES so that they can use appropriate technology in accessing the internet and printing for the BUMDES financial report. Provide assistance and training to groups that have been formed at BUMDES Catu Graha Mandiri, especially those related to trade, savings, loans, recreation, tourism activities, financial management, etc. This program is expected to improve the ability of the management of BUMDES Catu Graha Mandiri. This program is carried out by the Team assisted by information technology students of Dhyana Pura University. After the Management Business training of BUMDES Catu Graha Mandiri, Gumbrih Village the skills of BUMDES team members have improved better than before partnership activity.

\section{Counseling, and training in entrepreneurship management}

Partners are given training on consumer behavior according to the culture and ethics of the community (each business group such as trading, and savings loan, recreation, tourism activities, financial management of organic Farmers Sukadame and tour packages (such as water tours and ATVs)). By having professional human resources, consumers are satisfied, so that they can increase the knowledge of BUMDES human resources to satisfy consumers. This training is carried out by the university partnership implementation team assisted by hotel management students at Dhyana Pura University. After assistance, counseling, and training in entrepreneurship management for BUMDES Catu Graha Mandiri, Gumbrih Village the skills team members have improved better than before partnership activity. Figure 4 about Training on the Use of Computer Technology. 


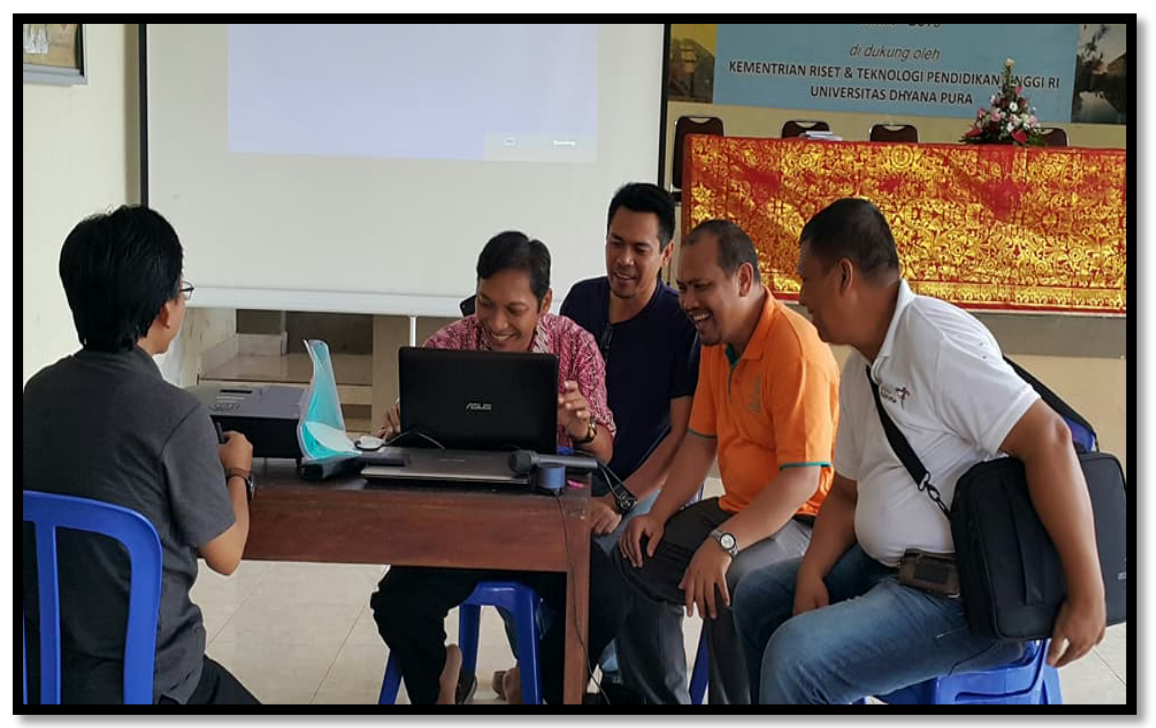

Fig. 4. Training on the use of computer technology

\section{Assistance and training in product marketing and services through print and social media}

Counseling and training in the marketing of products that are members of the BUMDES Catu Graha Mandiri correctly by using the internet, print media, and social media. Marketing is the main key in promoting and selling BUMDES Catu Graha Mandiri products. With the right promotion, it can increase sales turnover and develop this business for the welfare of members of the Catu Graha Mandiri BUMDES business group and the surrounding community. Besides that, it is also the creation of print media that allows promoting businesses such as trade, and savings loans, recreation, tourism activities, financial management, etc. This training was carried out by the university partnership implementation team assisted by students of information technology and information systems at Dhyana Pura University. The proposing team makes a business banner (as a promotional tool) to solve the marketing problem of the business. This program is expected to be able to increase the income of Catu Graha Mandiri BUMDES. Besides that, it also conducts training in making correct financial reports. This training was carried out by the university partnership implementation team assisted by Dhyana Pura University accounting students. After assistance, counseling, and training in the marketing of products for BUMDES Catu Graha Mandiri, Gumbrih Village the skills team members in digital marketing, and product packaging have improved better than before partnership activity. Figure 5 training on financial report making and entrepreneurship. 


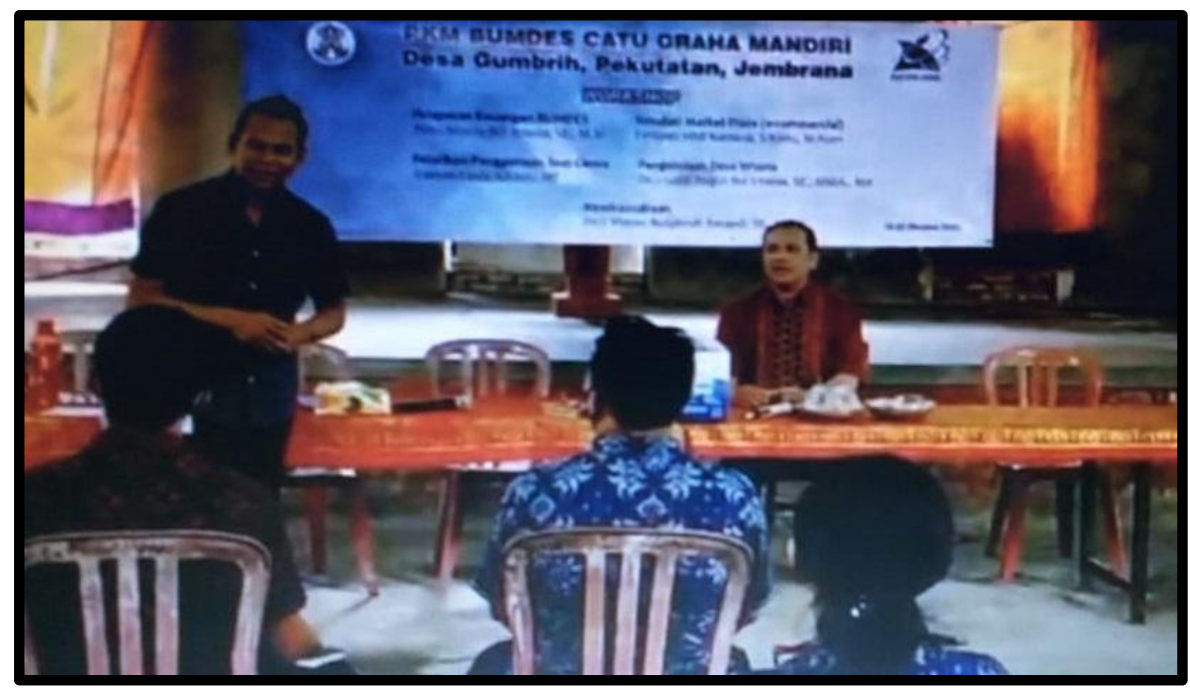

Fig. 5. Training on financial report making and entrepreneurship

\section{University Partnership for BUMDES Catu Graha Mandiri mentoring phase}

After completing the training phase, the BUMDES Catu Graha Mandiri business managers can manage their business independently. The University Partnership Team and experts will accompany each group member for several days so that they can ask questions if they experience difficulties during the trial of these activities. This mentoring also aims to remind group members if they make mistakes in the trial so that they are not different from the previous training material. The target to be achieved from this mentoring is so that all group members can manage their business independently and be able to develop their business potential which in turn increases Gumbrih's Village Original Revenue (PAD).

\section{University Partnership Monitoring Phase}

The monitoring phase was carried out by the implementation team, the Head of Gumbrih Village, and the Dhyana Pura University Research and Community Service team. At this monitoring phase, all activities must be able to see the improvement, starting from the training phase, mentoring, and the results that have been obtained by the management of BUMDES Catu Graha Mandiri. The target to be achieved from this monitoring is to confirm all phases and processes of all activities related to the Catu Graha Mandiri BUMDES. If there are unsatisfactory findings, the implementation team will accompany the areas or aspects that are less than optimal, so that they do not become findings again during the evaluation. 


\section{University Partnership in Evaluation Phase}

This evaluation phase is carried out after the specified period is almost complete. The implementing team, together with experts, and the Institute for Research and Community Service team, evaluate each performance of the managers of BUMDES Catu Graha Mandiri Gumbrih. Based on the results of the evaluation carried out by the implementation team, the group members and the chairperson were notified to correct deficiencies and provide additional assistance so that the results obtained were maximized. Implementing this evaluation is a team of proposers, experts, and the Chairperson of the Institute for Research and Community Service from Dhyana Pura University.

After we evaluate the implementation of this service program, the acceleration of knowledge and skills of the members can be explained in the following Table 2 below:

Table 2. Pre-test and post-test acceleration university partnership program for BUMDES Catu Graha Mandiri Gumbrih

\begin{tabular}{|c|c|c|c|c|c|c|c|}
\hline \multirow{2}{*}{ No } & \multirow{2}{*}{$\begin{array}{l}\text { Description of } \\
\text { programs }\end{array}$} & \multicolumn{2}{|c|}{ Pre-Test (Base line) } & \multicolumn{2}{|c|}{ Post Test (Actual) } & \multicolumn{2}{|c|}{ Acceleration (Post-Pre) } \\
\hline & & Knowledge & Skills & Knowledge & Skills & Knowledge & Skills \\
\hline 1 & \begin{tabular}{l}
\multicolumn{2}{l}{ Management } \\
Business training \\
(Finance report, \\
and Computer \\
Skills)
\end{tabular} & 3,50 & 3,30 & 4,10 & 4,40 & 0,60 & 1,10 \\
\hline 2 & $\begin{array}{l}\text { Assistance and } \\
\text { training in } \\
\text { entrepreneurship } \\
\text { management and } \\
\text { Business Start-up. }\end{array}$ & 3,30 & 3,40 & 4,20 & 4,30 & 0,90 & 0,90 \\
\hline 3 & $\begin{array}{l}\text { Assistance and } \\
\text { training in product } \\
\text { marketing and } \\
\text { services through } \\
\text { print and social } \\
\text { media. }\end{array}$ & 3,40 & 3,40 & 4,10 & 4,40 & 0,70 & 1,00 \\
\hline
\end{tabular}

$\mathrm{N}=10$ Respondents.

Likert Scale with Mean Remark: $(1.00-1.80=$ Very bad $),(1.81-2.60=$ Bad $),(2.61-3.40=$ Average $)$, $(3.41-4.20=$ Good $),(4.21-5.00=$ Very good $)$

Three empowerment programs were carried out, such as (1) Management Business training (Finance reports, and Computer Skills), (2) Assistance and training in entrepreneurship management and Business Start-up. (3) Assistance and training in product marketing and services through print and social media, all of which have an impact on the acceleration of the knowledge and skills of the participants. However, of the three programs, the Management 
Business training program has the highest impact, when compared to the Assistance and training program in product marketing and services, as well as Assistance and training in entrepreneurship management and Business Start-up.

\section{University Partnership for BUMDES Catu Graha Mandiri Sustainability Phase}

The program sustainability phase is a phase that is carried out based on the results of monitoring and evaluation of BUMDES Catu Graha Mandiri's business activities. The assessment of this phase was carried out by the implementation team, the Chairman of BUMDES, and the Institute for Research and Community Service. To sustain this program, each business group must increase its productivity and teach similar and different business groups. The goal is that other groups or other subak get the same knowledge so that the University Partnership Team and BUMDES Catu Graha Mandiri are felt by all members of the Gumbrih Village community. If members of the Catu Graha Mandiri BUMDES and other community members feel the benefits of this University Partnership Team, and BUMDES Catu Graha Mandiri, then the implementing team submits a second-year application regarding the sustainability of this program. Thus, the people of Gumbrih Village continue to improve their knowledge, skills and gain economic value, so that Gumbrih Village becomes a mainstay village in the West Bali region.

\section{Participation of Partners and Dhyana Pura University}

Partner participation and participation of Dhyana Pura University are needed in advancing the Community Partnership Program-BUMDES Catu Graha Mandiri. Given the very usefulness of this program for partners and Dhyana Pura University, starting from the introduction phase to the sustainability phase, partners and Universitas Dhyana Pura participate in:

\section{Partner Participation (Head of Gumbrih Village and BUMDES Catu Graha Mandiri).}

Each BUMDES Catu Graha Mandiri business group participates in preparing a place for socialization and training activities for this program. Besides, during the socialization and training, the group of partners provided consumption as a form of real contribution that they needed this program to increase their income. Since the beginning of the introduction of the University Partnership, and BUMDES Catu Graha Mandiri program, the Head of Gumbrih Village, and the Chairman of the BUMDES Catu Graha Mandiri have provided time to meet. 
They look forward to the help of Dhyana Pura University lecturers to foster and train community members in developing BUMDES Catu Graha Mandiri. Evidence from the Chairman of BUMDES Catu Graha Mandiri, supporting the Dhyana Pura University Internal Grants program is manifested through the signing of a 6000 stamped statement letter as attached to this proposal. The Village Head, the Chairman of BUMDES Catu Graha Mandiri, gathered his members at the Village Head's Office to hear the socialization and benefits of the Dhyana Pura University program.

\section{Dhyana Pura University's Participation}

University's Participation is realized through the making of an MOU between the Rector and the Head of Gumbrih Village. This participation was further realized through the presence of the Chancellor at the University Partnership program socialization opening ceremony and sending experts in hospitality management, accounting, tourism management, computer technology information staff, and allowing lecturers and 4 students from various study programs to be involved in these activities. Thus, this participation shows the empowerment of Dhyana Pura Bali University in implementing programs to improve the economy and welfare of the Indonesian people, especially the people of Gumbrih Tourism Village should be continued in other programs.

\section{Result and Discussion}

\section{The Implementation of the Partnership Program Use of Applied Technology}

The results of assistance, counseling, and training for BUMDES Catu Graha Mandiri have been able to use appropriate technology in accessing the internet and printing for BUMDES financial reports so that assistance is provided in the form of a modem and 1 set of printers on partner groups are very helpful. The use of appropriate technology can increase BUMDES businesses so that the sales turnover of BUMDES Catu Graha Mandiri increases at the end of October 2020.

\section{Entrepreneurship Training Program}

Results of mentoring, counseling, and training in the management of entrepreneurship management in the form of professional management. Partners are given training on consumer behavior according to culture and community ethics so that every business group such as trading businesses or shops, reptiles, Sukadame Organic Farmers, and tour packages such as water tours, and ATVs. 


\section{Digital Marketing Training Program}

Providing assistance, counseling, and training in the correct marketing of products that are members of POKMAS BUMDES using the internet and print media, and social media (FB, IG, and Line). Marketing is the main key in promoting and selling BUMDES products. With the right promotion, it can increase sales turnover and develop this business for the welfare of members of this BUMDES business group and the surrounding community.

\section{Conclusion}

\section{Monitoring and Monitoring Program Sustainability}

It has been carried out by the implementation team, the Head of Gumbrih Village, and the Dhyana Pura University Research and Community Service team. At this monitoring phase, all activities have seen an increase, starting from the training phase, mentoring, and the results that have been obtained by the management of BUMDES Catu Graha Mandiri. The evaluation was carried out in October 2020. The implementing team together with experts, and the Institute for Research and Community Service team, evaluated each performance of the managers of BUMDES Catu Graha Mandiri Gumbrih. Based on the results of the evaluation carried out by the implementation team, the group members and the chairperson were notified to correct deficiencies and provide additional assistance so that the results obtained were maximized. The sustainability of this partnership program is a phase carried out based on the results of monitoring and evaluation of BUMDES Catu Graha Mandiri's business activities.

The assessment of this phase was carried out by the implementation team, the Chairman of BUMDES, and the Institute for Research and Community Service. In the framework of the sustainability of this program, each business group must increase its productivity and teach similar and different business groups so that the people of Gumbrih Village continue to improve their knowledge, skills, and gain economic value so that Gumbrih Village becomes the mainstay village of Jembrana Regency.

\section{Acknowledgements}

We sincerely express gratitude profusely to the University of Dhyana Pura facilitating service activities in the program of Community Partnership Grant in 2020. 


\section{References}

Adinegara, G. N., Sirna, I. K., \& Sukmana, I. T. (2019). Tourists Motivation to Visit Tourism Village: A Case Study on Gumbrih Tourism Village-Bali. International Conference on Fundamental and Applied Research (I-CFAR).

Baum, J. R., Locke, E. A., \& Smith, K. G. (2001). A Multidimensional Model of Venture Growth. Academy of Management Journal, 44(2), 292-303.

Baumol, W. J., \& Bowen, W. G. (1993). Performing arts-the economic dilemma: a study of problems common to theater, opera, music, and dance. Gregg Revivals.

Kirzner, I. M. (1973). Entrepreneurship and Competition.

Brown, D. J., \& Heal, G. (1979). Equity, Efficiency, and Increasing Returns. The Review of Economic Studies, 46(4), 571-585.

Birch, L. L., McPhee, L., Shoba, B. C., Steinberg, L., \& Krehbiel, R. (1987). “Clean up Your Plate": Effects of Child Feeding Practices on the Conditioning of Meal Size. Learning and Motivation, 18(3), 301-317.

Bolton, J. E. (1971). Small Firms: Report of the Committee of Inquiry on Small Firm's Chairman JE Bolton. HM Stationery Office.

Priyanto, S. H., \& Sandjojo, I. (2005). Relationship Between Entrepreneurial Learning, Entrepreneurial Competencies and Venture Success: An Empirical Study on SMEs.

Utama, I. B. (2016). Positioning Eco-Tourism for Improving Destination Image of Bali Indonesia. E-Journal of Tourism.

Utama, I. B. (2014). Agrotourism as an Alternative Form of Tourism in Bali Indonesia. Summary of Paperback: Scholars' Press (October 22, 2014), ISBN-10: 3639667123, ISBN-13, pp. 978-3639667127. 